UDC 331.101.38

DOI: http://dx.doi.org/10.26642/pbo-2019-2(43)-65-68

O.M. Svintsytska, Candidate of Economic Sciences

Zhytomyr Polytechnic State University

\title{
Priority factors of the development of long-term motivation of work of staff
}

\begin{abstract}
The article is devoted to the problem of motivation of work in the context of providing a stable positive result in the long-term life of the enterprise. The desire of the employer to constantly maintain the capacity and development of which necessarily leads to a review of incentives for work, a combination of economic instruments of fulfillment the workers' needs with socio-psychological methods of influencing their behavior in the team in accordance with the interests and needs of identified groups of workers at different stages of their professional life. The task of the modern manager is to find his own incentive for each employee, beginning from involvement to a simple social project and ending with the creation of conditions for professional growth and self-realization. Particularly, the emphasis is to be made on positive image and reputation of the enterprise among all market participants, corporate social responsibility and involvement of all employees in participation in the development of the company, becoming the priority factors for the development of the motivation of employees and creating the necessary foundation for sustainable economic development of the enterprise. These aptects strategically provide the development of positive motivation of the staff and determine the relevance, purpose and content of scientific research.
\end{abstract}

Keywords: motivation; social motives; socio-psychological methods; long-term motivation; staff development.

Introduction. Implementation of socio-economic and political reforms in the country led to the need for adaptation of enterprises to a changing market environment, the search for a new paradigm of staff management and the development of measures for long-term motivation of work. It is based on the socio-psychological aspect of stimulating the development of work relations, which are manifested at different levels: employee-employee; employee-employer; trade union-employer; employer-state; employee-state, etc. If ensure harmonious coincidence of interests of all these subjects and the coincidence of the system of incentives to employee's expectations, then one can expect the increase of the motivation in the long term, which will be positively reflected in the results of the work of the entire enterprise. The significant contribution into the research of social-labor relations and work motivation in the system of staff management at both macro and micro levels has been made by Ukrainian scientists, in particular, Tereschenko V.K, Kolot A.M, Krushelnytska O.V., Melnichuk D. P., Grinova V.M., Gaiduchenko S.O., Zakharova O.V., Savchenko V.A, Kirichenko O.A. etc. However, today there is a need to broaden the theoretical and methodological foundations of the development of long-term motivation of the enterprise's staff due to modern trends in the development of the environment. The relevance of this study is aimed at overcoming the consequences of insufficient motivation, which limits the realization of potential opportunities of the enterprise, as well as the identification of priority factors for the development of long-term motivation that would stimulate the actions of both employers and workers in a particular direction, creating certain motives for employee behavior in the labor market.

Setting objectives. The main purpose of the scientific article is to identify the priority of sociopsychological factors of influence on the positive development of staff motivation in the long perspective in order to ensure a harmonious coincidence of interests of all subjects in the labor market.

Methodology. In the process of research, the following general scientific methods were used: the systematic approach - to develop a system of motives of work activity, generalization, analysis and synthesis - for determination of the priority factors of influence on the development of motivation, and also special methods, in particular, the comparative analysis - in the process of research of long-term motives in the interrelation with the business results of the enterprise, expert assessments - in the analysis and justification of trends in the system of socio-psychological motivation of staff.

Research results. During the periods of socio-political shock, changes in the structure, economic system, together with the outlook of people, interests, behavior and motives of their activities, objectively change work values. In such circumstances, an objective and understandable becomes situation when the economic transformations in our country will not succeed unless the system of the development of staff motivation is radically changed. After all, the enterprise as an employer should be attractive to its potential employees not only during the post replacement, but also in its future establishment and development. Only then there may be a desire to study and develop for further work in the enterprise [9]. This goal is achieved only by identifying and meeting the needs of each individual employee to achieve personal goals and objectives of the organization.

(c) O.M. Svintsytska, 2019 
The main thing for the employer here stays the identification of individual groups of workers in accordance with their work interests and needs in order to develop a long-term perspective plan of motivation in connection with the stages of enterprise development, the personal potential of employees and their motivational expectations. For an employee, it is the degree of satisfaction with work, that is, an assessment of the ability to implement their claims to the content, character and conditions of work, both in the current period and in the future are determined the main [3].

The desire of the employer to maintain constantly the capacity and positive motivation of employees necessarily leads to a constant review of the incentives of work, a combination of economic instruments of satisfaction of the needs of workers with socio-psychological methods of influence into their behavior in the team according to the interests and needs of the identified groups of workers at different stages of their professional life. These aspects strategically provide motivation for the development of positive staff motivation. That's why, in this research under the development of motivation we will understand [1, C.126-127]:

- "elementary" and "further" motivation of the employed person;

- changes that take place in his motivation under the influence of above mentioned or other factors, including incentive systems.

Depending on types of needs (material, cultural or social) and priorities at one or another stage of life, different groups of motives are formed. These motives according to the hierarchy of needs are widely described in many textbooks from the theory and practice of personnel management and management basics. Among them, the most famous theory is of A. Maslow, which is based on a certain hierarchy of human needs. Despite the classical approach to the problem and the relative conditionality of the hierarchical representation of the needs and interests of employees, it can serve as a sufficiently accurate indicator of the development of a system of methods which are responsible for the qualitative composition of the staff of the enterprise.

Taking into account other theories of motivation, in particular K. Alderfer and F. Herzberg, it is worth considering the absence of the clear hierarchy in the human needs, the allocation of a broader range of needs, their movement from the bottom to the top and vice versa, and also the existence of parallel relationships between levels depending on the factors of external and internal influence on a person. That's why, the composition of the methods of motivation should reflect both the structure of the hierarchy of the needs of employees, and their priority, which corresponds to the interests, abilities of people who work at the enterprise at one time or another.

The strength of motivation directly depends on the value of the employee of the proposed work remuneration. And vice versa, when an employee can't satisfy his needs through productive and honest work, motivation is reduced, work ideals lose sense. This is observed in the modern labour market, when the current level of salary does not provide the employee with the volume of consumption of material goods and services sufficient for the expanded reproduction of his physical and intellectual ability to work [8].

On this basis, the shift of work emphasis to the socio-psychological aspects of work and the strengthening of the role of non-material motivation is observed. Socio-psychological methods act as regulators of social, psychological, ideological and ethical relationships in the team. A large number of psychological factors are reflected the results of work. The ability to take them into consideration helps the manger to influence deliberately certain employees and form a team with common goals. Besides, for the effective management of the team it is necessary to know the moral and psychological characteristics of certain workers, sociopsychological characteristics of certain groups, their motives in work. [4]

These are social motives that are formed under the influence of the environment and have special significance for work motivation, for the formation of that behavior in the work which is expected (desirable) from each employee. This is the desire to be a member of a team (group): self-affirmation i.e. an attempt to secure self-recognition; motive to reach the success in work, creativity in work, overcoming of service steps; the motive of independence of making the decisions; the motive of self-realization i.e. the desire to show abilities in the work; motive of protection of self situation; the motive of acquisition, the possession of material values; altruistic motive i.e. the desire to help others without any benefit to yourself and others.

Taking into consideration these motives, active search and application of appropriate incentives of employees' work activity is observed, and also their role at different stages of enterprise development is intensified, taking into consideration the priorities of needs, work interests and goals of the team.

According to research of Hay Group company, which is one of the world's leading consulting companies in human capital management, there have been positive trends in staff motivation over the past two years observed. Among a number of economic factors that form the social environment of the enterprise, one of the main is remuneration for work. Salary and other forms of work remuneration combine the main economic interests of the enterprise and the personal and group interests of workers, and also concentrate different in meaning but closely interconnected elements: labor costs, productivity of work, social the status of workers, social justice, etc.

Many enterprises are trying to attract specialists by exactly social payments and privileges, which are becoming an important and necessary condition for maintaining stability in society and improving the living standards of workers and the members of their families. This kind of income, like salary and dividends, depends 
directly on the results of each employee's work and the company as a whole, because its source is mainly profit received from economic activity. So, as participants of the system of social privileges and payments, workers are interested in the final results of production activity.

Besides the raising of salary, for key employees and employees who mainly occupy commercial positions, conditions for participation in management of the enterprise are created, equality and fairness in setting work standards, distribution of work, assessments and rewards are provided, democratic style of management, equal opportunities, the only status of workers, the observance of safety equipment norms, medical insurance privileges, trainings, study, etc. are used.

Competitive advantages of enterprises are provided by the understanding of the leaders of the social behavior regularities and the individual psyche of the employee, and as a result, there is a change in the orientations on the personal results of employees. The task of the modern manager is to find his own incentive for each employee, starting from attracting to a simple social project and ending with the creation of conditions for professional growth and self-realization.

Exactly the emphasis on positive image and reputation of the enterprise among all market participants, corporate social responsibility and involvement of all employees in participation in the development of the company, are becoming the priority factors for the development of the motivation of employees and creating the necessary foundation for sustainable economic development of the enterprise. An involved employee on such basis feels internal satisfaction with his work, working conditions, social status and his own participation in the activities of the team, which induce to increase his professional skills in the workplace, level of responsibility and obtaining authority. Such approach also reflects the levels of motivation according to the needs of the Maslow Pyramid, where the main vector is directed from simple material satisfaction to the desire to be part of a successful company, that is, employees are involved in business processes, satisfying the needs of the second and third levels, in particular, belonging to success, significance and self-realization. In this case, motivational expectations act as a powerful stimulator to increase self professional productivity and have a stable character which significantly affects business results.

The practical significance of such an approach to the development of long-term motivation is emphasized by experts in staff management, the essence of which is to increase the efficiency of the enterprise for at least $40 \%$, the level of service satisfaction in average of $18 \%$ and the growth of financial indicators by 4-4.5 times, while the turnover of staff decreases by $14 \%$ [6]. Table 1 shows the benefits of involving employees into enterprise development.

Table 1

Main benefits of motivating employees to participate in enterprise development

\begin{tabular}{|l|l|l|l|}
\hline \multicolumn{1}{|c|}{ Commitment } & \multicolumn{1}{|c|}{ Initiative } & \multicolumn{1}{c|}{ Enthusiasm } & \multicolumn{1}{c|}{$\begin{array}{c}\text { Integrity and } \\
\text { Responsibility }\end{array}$} \\
\hline $\begin{array}{l}\text { Promotes the interest in } \\
\text { the success of the } \\
\text { company }\end{array}$ & $\begin{array}{l}\text { Improves and optimizes } \\
\text { business processes }\end{array}$ & $\begin{array}{l}\text { Increases productivity of } \\
\text { work }\end{array}$ & $\begin{array}{l}\text { Promotes the observance } \\
\text { of quality standards and } \\
\text { regulatory standards }\end{array}$ \\
\hline $\begin{array}{l}\text { Improves the dedication } \\
\text { and quality and } \\
\text { performed tasks }\end{array}$ & $\begin{array}{l}\text { Provides flexibility and } \\
\text { speed tasks fulfilment }\end{array}$ & $\begin{array}{l}\text { It leads to growth of } \\
\text { consumer affinity }\end{array}$ & $\begin{array}{l}\text { Provides a positive } \\
\text { reputation }\end{array}$ \\
\hline $\begin{array}{l}\text { Focuses on achieving } \\
\text { goals }\end{array}$ & $\begin{array}{l}\text { Promotes the } \\
\text { development of new ideas } \\
\text { and opportunities }\end{array}$ & $\begin{array}{l}\text { Provides effectiveness of } \\
\text { team collaboration }\end{array}$ & $\begin{array}{l}\text { Allows to accomplish set } \\
\text { tasks at the proper level }\end{array}$ \\
\hline
\end{tabular}

By providing the benefits of socio-psychological motivation, the management determines the tools for successful realization of the tasks, in particular, it is the clear communication of the goals and values of the work of employees, objective / positive assessment of work, distribution of tasks by interests, emphasis on the strengths of employees, providing opportunities for daily use of their own abilities, the desire to listen and discuss real problems, etc. [6].

Conclusions. The scientific novelty of the results lies in broadening existing and developing new approaches for constructing long-term motives of work activity on the basis of socio-psychological methods, with an emphasis on attracting employees to participate in enterprise development.

The substantiation of the main advantages of involving employees in participation in the development of the enterprise through the motivation of their commitment, initiative, enthusiasm, integrity and accountability to work shows the interconnection of the success of the enterprise with the long-term motivation of the staff both at the level of the whole team and at the level of a specific employee. The emphasis on socio-psychological factors in the development of staff motivation contributes to the attraction of highly skilled workers, the preservation of groups during the required period; maintaining the competitiveness of the company in the labor market by 
offering more favorable incentives for employees in comparison with other enterprises; to stimulate productivity. These trends are closely interwoven, interdependent and supplemented by socio-economic indicators of enterprise development.

\section{References:}

1. Voitenko, A.I., (2010), Organization, management and administration in social work, Textbook, Infra-M, Moscow, $255 \mathrm{p}$.

2. Grinyova, V.M., Novikov, M.M., Salun, M.M. and other (2010), Administrative management of work potential, Tutorial, in Grinyova, V.M. (ed.), HNEU, Kharkiv, 428 p.

3. Dvoretska, G.V. (2002), Sociology, Tutorial, KNEU, Kyiv, 472 p.

4. Kiptenko, V.K. (2010), Tourism Managemen, Textbook, Knowledge, Kyiv, 502 p.

5. Krushelnytska, O.V. and Melnichuk, D.P. (2005), Staff management, Textbook, Condor, Kyiv, 308 p.

6. Romanenko, I. (2016), «How to keep the team and involve it into the work process», Staff manager, Kyiv, No. 5, pp. 6-18.

7. Savchenko, V.A. (2008), Management of staff development, Tutorial, KNEU, Kyiv, 351 p.

8. Semikina, M. (2001), "Aspects of restructuring the mentality of employees in the system of motivational management», Ukraine: aspects of work, Kyiv, No. 4, pp. 40-46.

9. Stakhov, O.V. (2008), «Monitoring of motivation of employees as a means of increasing the competitiveness of the enterprise», Demography and social economics, Kyiv, No. 2 (10), pp.134-143.

10. Porshneva, A.G, Rumyantsev, Z.P. and Salomatina, N.A. (1999), Management of the organization, Textbook, InfraM, Moscow, 669 p.

Свінцицька Олександра Миколаївна - кандидат економічних наук, доцент кафедри управління персоналом та економіки праці Державного університету «Житомирська політехніка».

Наукові інтереси:

- креативна економіка і управління,;

- коучинг і наставництво, лідерство й управління командами.

Стаття надійшла до редакції 16.05.2019. 